This is an Author's Accepted Manuscript of a chapter in Remael, Aline; Pilar, Orero; Mary, Carroll (eds.) Audiovisual Translation and Media Accessibility at the Crossroads. Media for All 3. Amsterdam / New York: Rodopi, 173-188, available here: http://www.rodopi.nl/functions/search.asp?Bookld=ATS+36

\title{
Audio Description Made to Measure: Reflections on Interpretation in AD Based on the Pear Tree Project Data
}

\author{
Iwona Mazur \\ Adam Mickiewicz University (Poland) \\ Agnieszka Chmiel \\ Adam Mickiewicz University (Poland)
}

\begin{abstract}
The issue of interpretation in audio description continues to divide both AD practitioners and researchers. In this contribution we look at interpretation from the point of view of narratological behaviour of sighted viewers. To this end, we analyse data from twelve languages collected in the Pear Tree Project - a research project in which sighted viewers were asked to watch a short film and subsequently recount what they saw. Linking our findings to AD, we find in our analysis that sighted viewers interpret visual events but they avoid extremely subjective interpretations or interpretations in which they pass moral judgments. Thus, we propose that instead of applying the binary opposition of objective versus subjective, we should rather be using an objectivity- subjectivity scale, which can help determine which interpretive descriptions are less subjective and can consequently be used in AD without running the risk of being patronising or spoonfeeding the sense to the visually impaired.
\end{abstract}

Keywords: audio description, reception studies, interpretation, facial expressions, Pear Tree Project

\section{Introduction}

To date efforts in audio-description (AD) research have primarily focused on determining the specific requirements of its end users (i.e., blind and partially sighted audiences) through reception studies (e.g., in the Audetel Project and Bollywood for all conducted by the Royal National Institute of Blind People in the UK) to develop standards that ensure the uniformity and high quality of AD. However, to date no consistent guidelines have been created because the preferences of the users concerned often vary from person to person and because audio description has developed on the basis of what a limited number of practitioners - as a result of their own experiences - believe to be the right way to proceed.

One issue where there is no agreement among target audiences or AD researchers is interpretation. In this contribution, interpretation is understood as the subjective treatment of reality perceived by audio describers in films and the equally subjective verbal expression of that reality in description for the blind and partially sighted. In general - and especially in early AD guidelines - subjective judgments are not welcome in AD and objectivity is favoured in order to avoid any manipulation, spoon-feeding or a patronising attitude towards the target audience. However, it is not always clear what constitutes subjective judgment and what kind of interpretation is more objective and could be included in AD.

Although we are ardent supporters of learning the preferences of visually challenged audiences through reception studies, in this contribution we suggest looking at the narrative practices of sighted viewers in general to determine whether they interpret visual events by using value judgments or evaluative words and, if so, to what extent. Such data could provide us with insights into what constitutes the objective description of events that could be included in AD, and what makes descriptions subjective and thus undesired in AD.

To this end, we reanalyse some of the data collected in the Pear Tree Project, which is briefly described below. We focus on the interpretation of three events depicted in the film used in the study. We are particularly interested in whether the descriptions of those events are interpretative. Before providing both the quantitative and qualitative analyses of the data and drawing conclusions, we present the varied - and often opposing - points of view in $\mathrm{AD}$ practice and research about interpretation in $\mathrm{AD}$.

\section{Interpretation in audio description: A bone of contention}

Audio description is defined as an audio commentary accompanying films, theatre performances and the like in order to give the blind and partially sighted access to visual elements of a cultural event. Thus, AD includes descriptions of characters, settings, actions and objects appearing on the screen or stage. According to Snyder, "AD is about democracy" (2005: 16) since it offers sighted and non-sighted viewers an equal opportunity to enjoy the arts and entertainment under comparable circumstances. In this respect, it is no wonder that many AD scholars, practitioners and guidelines mention objectivity as one of the key principles of AD (Dosch \& Benecke 2004, Orero 2005, Snyder 2005, Remael 2005, Vercauteren 2006). According to the ITC Guidance On Standards for Audio Description, one of the most comprehensive sets of AD best practices to date, "describers should not voice a personal opinion or interpret events" (2000: 15). Experts frequently refer to the WYSIWYG principle (What You See Is What You Get), which states that we should describe only what we can see and should avoid 
This is an Author's Accepted Manuscript of a chapter in Remael, Aline; Pilar, Orero; Mary, Carroll (eds.) Audiovisual Translation and Media Accessibility at the Crossroads. Media for All 3. Amsterdam / New York: Rodopi, 173-188, available here:

http://www.rodopi.nl/functions/search.asp?Bookld=ATS+36

subjective interpretation (Snyder 2007: 4). Pfanstiehl and Pfanstiehl note that describers are cautioned "not [to] evaluate or interpret, but rather be like the faithful lens of a camera" (quoted after Udo and Fels 2009: 179, as quoted in The Play's the Thing 1985: 91) and instructed to describe visual stimuli without drawing any assumptions for blind audiences.

However, it is not always easy to be objective. An equally large number of publications on AD (mainly in Europe, but also in Canada) refer to the interpret-or-not problem. Udo and Fels (2009: 179) claim that the task of objective interpretation is impossible. Hyks admits that AD is highly subjective - despite the describers' efforts and refers to this feature of $\mathrm{AD}$ as follows:

[E]ven though we all agree on certain basic principles, we do see things differently and we certainly express them in very varied ways (...) [and] even though we are observers, narrators, storytellers, witnesses to what is happening on screen, what we choose to include, differs $(. .$.$) from company to company and certainly from country to country. (2006: 1)$

Much in the same vein, Pujol and Orero (2007) state that although audio describers may strive to be as objective as possible, their choices will nevertheless be determined by individual ways of perceiving reality.

It seems that the US tradition favours a strictly objective approach (as frequently voiced by Snyder: "The blind viewer has the right to be as clueless as the sighted one", personal communication) whereas European scholars are much more sensitive to the blurred division between what is objective and what is subjective. The previously quoted ITC Guidance states the following:

Describers in the US are not encouraged to add anything or offer any information that is not apparent on the screen at that moment. Rather than saying a character is angry, they describe the action as they see it and let the visually impaired viewer decide what that action implies. British research seems to indicate that additional help is appreciated, as long as it is not condescending or interpretative. (2000: 15)

The same document emphasises that $\mathrm{AD}$ "is there to clarify what is going on but occasionally a little additional explanation can help" (ITC Guidance 2000: 15). However, interpretation is a bone of contention not only across the Atlantic but also in Europe. For instance, Holland (2009) - a long-term audio describer for the theatre in the UK - claims that although it might not be possible for audio describers to avoid interpretation altogether, they should try to be non-judgmental.

An interesting approach to objectivity and subjectivity in $\mathrm{AD}$ - based on Relevance Theory - is presented by Braun (2007). According to this model of communication, utterances are understood following explicatures (assumptions made explicitly by the speaker) and implicatures (assumptions implicated by the speaker). Braun presents examples from the film The Hours to show that audio describers have to make a whole series of inferences based on individual interpretation to understand seemingly factual content. Braun suggests that the identification of implicatures and explicatures can be useful to the audio describer when deciding the extent to which the visual stimuli should be described, and the extent to which the visual stimuli can be interpreted. She claims that the processing load of the $\mathrm{AD}$ audience can be reduced by verbalising "explicatures instead of the individual cues by which they are triggered" (Braun 2007: 10). Braun opposes the verbalisation of implicatures since it would not allow for individual interpretation (i.e., for drawing implicatures) by the blind audience.

In order to shed more light on the contentious issue of interpretation in $\mathrm{AD}$, let us look at specific examples. We will first review some examples of interpretation that can be classified without any doubt as unacceptable and unnecessary. We will then proceed to discuss less obvious instances where interpretation should be carefully considered before deemed justified or undesired.

Remael (2005) presents an obvious example of unnecessary interpretation and spoon-feeding the sense of the visual material to the blind audience. A scene in which a character is tossing around in bed at night should not be interpreted as "She's having a nightmare". Movements of the character should be described instead to let the blind viewers make appropriate inferences for themselves.

Chmiel and Mazur (forthcoming) review early AD attempts in Poland and enumerate some examples of erroneous and excessive interpretation from Ice Age 2. A scene in which Manny and Ellie - the two leading characters - go for a walk and strike up a rather intimate conversation about their personal lives marks the beginning of a relationship that develops later in the film. In the Polish AD, the event is interpreted as a date and described as follows: "Diego i Sid, widząc, że zanosi się na randkę, oddalają się w swoją stronę" [Seeing that they are about to go out on a date, Diego and Sid leave]. In this instance, it is unlikely that such interpretation would be considered acceptable. By way of comparison, in the English AD, the event is described neutrally and objectively: "Manny and Ellie heading for the campsite".

The above examples are obviously at variance with AD guidelines and the principle of objectivity. However, the issue of interpretation in $\mathrm{AD}$ is most controversial in cases where the difference between objective and subjective is less obvious and where objective description is impossible due to linguistic or time constraints. 
This is an Author's Accepted Manuscript of a chapter in Remael, Aline; Pilar, Orero; Mary, Carroll (eds.) Audiovisual Translation and Media Accessibility at the Crossroads. Media for All 3. Amsterdam / New York: Rodopi, 173-188, available here:

http://www.rodopi.nl/functions/search.asp?Bookld=ATS+36

These cases include the use of evaluative adjectives in describing characters, descriptions of facial expressions and the use of adverbs in order to enrich the description.

\subsection{Evaluative adjectives in $\mathrm{AD}$}

Evaluative adjectives such as beautiful, awful, ugly manifest subjective interpretations of the visual material by the audio describer since viewers may have different perceptions of what is beautiful, awful or ugly. They provide concise descriptions but may be considered manipulation of the film. Surprisingly, in a small-scale AD reception study conducted by Mazur and Chmiel (manuscript in preparation) involving 18 respondents with sight dysfunction, the majority of the respondents $(71 \%)$ claimed that they like descriptions with evaluative adjectives. To examine the issue further, the authors asked the same respondents to judge whether in their opinion specific evaluative adjectives are objective or subjective. More than half participants (62\%) judged the phrase sexy brunettes as subjective. This phrase was also questioned by visually-impaired consultants who reviewed the AD script including this and other descriptions used in the survey. $46 \%$ of respondents viewed the phrase attractive singer as subjective, and the remaining examples (e.g., smart clothes) were identified as objective by the majority of participants ( $62 \%$ to $77 \%)$. Paradoxically, $54 \%$ of respondents claimed that, in general, they do not accept audio description with subjective interpretations. The results are inconclusive and more research is needed with larger samples to allow for generalizations.

All of the above examples may be reformulated in a more neutral way, provided there are no time constraints in the film and longer descriptions fit between dialogues. For instance, the adjective sexy can be replaced with more objective characteristics of those sexy characters such as long legs, large bosoms, etc. Viewers can use this information to decide if the characters are sexy or not, depending on their perception of sex appeal. Similarly, attractive can be described by specific features that make the singer attractive in the audio describer's opinion. Smart clothes can also be replaced with a more detailed description of individual garments. However, under time constraints, that is, when longer descriptions cannot be included in the script and the identification of such features is important for the plot, the use of such evaluative adjectives should seriously be considered by audio describers.

\subsection{Describing facial expressions}

Facial expressions are extremely difficult to describe objectively and briefly since the human face is able to express highly complex emotions thanks to numerous muscles (Mazur \& Chmiel, manuscript in preparation). Although a subjectively interpreted emotion of joy can be described objectively by mentioning the action of smiling (the same with sadness and crying), there are many more complex emotions and facial expressions that are difficult to describe objectively without naming them subjectively (e.g., concern, confusion, selfconsciousness). The audio describer can resort to describing facial expressions but emotions are always more subtle. For example, a seemingly simple act of raising eyebrows can point to anxiety, relief, surprise, wryness and many other emotions when combined with movements of other facial muscles.

Dosch and Benecke (2004: 24) also underline the tricky issue of facial expressions in AD:

Besonders vorsichtig muss man sein, wenn es um die Beschreibung von Gesichtsausdrucken geht, die ja immer etwas über den Gefühlszustand einer Person sagen. Hier besteht die Gefahr, durch zu plumpe Erklärungen einen Film zu verflachen (...). Statt solcher 08-15-Begriffe (...) sollte man sich die Zeit nehmen, die wirklich wichtigen Gesichtausdrücke (und nur diese!) differenzierter zu beschreiben (...). (Beispiel: Statt "Angespannt sieht er sie an" vielleicht: "Er hat die Augen zusammengekniffen, seine Wangen sind gerötet, die Lippen zusammengepresst”).

You have to be extremely cautious when describing facial expressions that always say something about the character's emotions. The danger is that awkward explanations can distort the profoundness of the film (...). Instead of such strict and constraining notions (...) the audio describer should take time to describe those really important facial expressions (and only those!) in a more sophisticated way (...). (For example: instead of "He looks at her nervously" the following description could be used: "He squints,, his cheeks are flushed, his lips pressed together"). (our translation)

We are not convinced that such descriptions can cover the whole range of mixed and complex feelings visible on film characters' faces and be as comprehensible and as easy to interpret by a blind audience as by a sighted audience. This issue requires further research involving blind and partially-sighted participants exposed to two different $\mathrm{AD}$ scripts - one including detailed and objective descriptions and the other with briefer descriptions with more explicit and subjective naming of emotional states. Comprehension tests and surveys of preferences should provide valuable guidance to audio describers.

Dosch and Benecke (2004: 24) are aware of the problem of time constraints when applying lengthy descriptions of facial expressions: "Fairerweise muss man ergänzen, dass es sich angesichts der oft kurzen 
Dialogpausen nicht immer vermeiden lässt, einen Gesichtsausdruck auf die kurze Art zu beschreiben." [To be fair, it has to be added that because of short pauses between dialogues, the need to describe facial expressions succinctly cannot always be avoided.] (our translation). Indeed, time constraints may pose a more serious problem to the description of facial expression than the plausibility of appropriate reflecting of emotional states in objective terms. Despite acknowledging the problem, Dosch and Benecke do not offer any solutions. A good example of such a problematic scene is given by Chmiel and Mazur (forthcoming). In the Polish film $A$ Warm Heart [Serce na dtoni], two male characters are seated in a limousine that has to swerve to avoid hitting an elderly lady on a motorcycle who tries to block their way and stop the car. The two men exchange surprised looks. The surprise is only subtly visible on their faces. The sighted viewers simply interpret their looks in this way based on their experience of reading human faces, looks and body language. Additionally, there is very little time between the dialogue. Consequently, a longer description would not fit in the pause. The alternative here seems to be either to use the interpretative description and mention the 'exchange of surprised looks' or to lose some content and resort to the exchange of looks only.

Orero and Vercauteren (manuscript in preparation) tackle the issue from a cognitive and narrative perspective. They claim that $\mathrm{AD}$ should include subjective descriptions of emotions since various studies confirm that at least some emotions are universal and correctly identified. They provide interesting examples of such objective and subjective descriptions. The following description: the upper eyelids and brows rise, and the jaw drops open can simply be replaced with a subjective (yet quite universal) interpretation of this expression: surprise. Similarly, the following description can adequately be replaced with the word angry: both the lower and upper eyelids tighten as the brows lower and draw together; the jaw thrusts forward, the lips press together, and the lower lip pushes up a little (Orero \& Vercauteren, manuscript in preparation). Apart from the obvious time saving (always an asset in audio description), the subjective descriptions do not present the listeners with a heavy cognitive processing load, which is the case when lengthy objective descriptions are used.

\subsection{Adverbs}

The use of expressive adverbs is encouraged since they can enrich descriptions and modify described actions. According to Rai, "adverbs are a useful shorthand to describing emotions and actions, but should not be subjective" (2009: 93). Similarly, the ITC guidelines (ITC Guidance 2000) encourage the use of verbs modified with adverbs, but warn audio describers to be cautious. The reason is that some adverbs are descriptive and specific while others can be vague and interpretative. Thus, the descriptive and specific adverbs should be used and the vague and interpretative adverbs should be avoided. The document presents examples of undesired adverbs (e.g., arguably, characteristically, clearly, instinctively, suitably). The meaning of such adverbs is indeed vague and they have no added value for AD. The list of descriptive and specific adverbs includes the following: anxiously, brusquely, carefully, cautiously, eagerly, haughtily, jovially (ITC Guidance 2000: 21). Interestingly enough, adverbs such as anxiously and jovially can actually be classified as interpretative since they imply that the character feels anxious or jovial, which is inferred subjectively by the audio describer. All in all, it seems that the issue of subjective interpretations in $\mathrm{AD}$ is quite complex since there are contradictory views regarding not only the acceptability of interpretations under certain circumstances but also the classification of certain words and expressions as objective or subjective.

\section{Analysed data}

Given the opposing points of view with regard to interpretation in audio description presented above, as well as the blurred division between interpretation that is more subjective or objective, we thought it useful to investigate whether sighted viewers interpret certain events when talking about a film and, if so, how they do it. Such data could help us determine which interpretative descriptions would be considered more universal and objective, and thus more acceptable by blind and partially sighted viewers as well. To this end, we have used data collected in the Pear Tree Project (PTP) conducted as part of the EU-funded DTV4ALL project, whose primary objective was to uncover dominant narrative patterns across a number of languages to determine whether development of common European AD guidelines is possible.

Twelve languages were included in the project: Afrikaans, Catalan, Dutch, English (UK and US), French, German, Greek, Italian, Irish English, Polish, Spanish (European and US). ${ }^{i}$ The subjects (20-25 for each language) were asked to watch a 6-minute film, in colour, with sound but with no dialogue. The film presented a chain of events related to a boy riding a bicycle and a man picking pears (for a detailed summary of the plot of the film see Du Bois 1980: xii-xiii). Having watched the film, the subjects were asked to recount what they had seen, in writing (for a detailed description of the project, including its objectives, participants, methodology, design and results see Mazur and Chmiel (manuscript in preparation). The project was modelled on an earlier 
This is an Author's Accepted Manuscript of a chapter in Remael, Aline; Pilar, Orero; Mary, Carroll (eds.) Audiovisual Translation and Media Accessibility at the Crossroads. Media for All 3. Amsterdam / New York: Rodopi, 173-188, available here:

http://www.rodopi.nl/functions/search.asp?Bookld=ATS+36

project conducted by Chafe and his co-workers in the mid-1970s (Chafe 1980). However, the analysis of the data was based on that of Tannen's related to Chafe's project (Tannen 1980).

Of the thirteen aspects analysed in the Pear Tree Project, we present three aspects below that tackle the issue of interpretation in descriptions of visual events, that is, giving pears to the boys, taking the basket, and the pearpicker's discovery that the basket is gone. We thought it interesting to see whether descriptions of those events provide a neutral account of what has happened or whether they are interpretations of those events, and if so, how. Therefore, what follows is both a quantitative and a qualitative analysis of the three aspects under consideration. It is important to stress that the original PTP analysis was solely quantitative and the data were compared and contrasted crosslinguistically to find both similarities and differences in the reception of visual images across all of the languages (and cultures) under consideration. However, in this contribition we are predominantly concerned with analysing the data holistically to make some general observations about the description of the visual input - irrespective of the language (or culture) concerned.

\section{Interpretation of events: Data analysis}

In this section, we present and analyse data with regard to three aspects of the PTP: (1) giving the pears to the boys, (2) the boy taking the pears and (3) the pearpicker's discovery that the basket is gone. First, we briefly recount a given event and the purpose of its analysis. Subsequently, we present the collected data. Finally, we analyse the data in terms of their relevance for interpretation in AD.

\subsection{Giving the pears to the boys}

In one of the scenes from the short film a boy falls off a bike and loses his hat, which is returned to him by three boys. Having got the hat back, the boy gives the three boys a pear each. In the analysis of this aspect, we wanted to see how many descriptions give just a basic rendering of this event, how many do not mention this event at all, in how many this event is interpreted as a gesture of thanks (e.g. the boy gave them a pear in return for their help) and how many provide a (moral) judgment of this event (e.g. as he should do, the boy gave them a pear in return for their help). The last two descriptions would indicate that there is some degree of interpretation on the part of the describers. However, it should be noted that when placed on a scale, the former would be much less subjective than the latter. Table 1 presents the results of the analysis, broken down into individual languages. What we are most interested in, however, are the overall results for all the languages combined. 
This is an Author's Accepted Manuscript of a chapter in Remael, Aline; Pilar, Orero; Mary, Carroll (eds.) Audiovisual Translation and Media Accessibility at the Crossroads. Media for All 3. Amsterdam / New York: Rodopi, 173-188, available here:

http://www.rodopi.nl/functions/search.asp?Bookld=ATS+36

Table 1. Results giving the pears to the boys (in percent)

\begin{tabular}{lrrrr}
\hline & \multicolumn{4}{c}{ Reference to event } \\
\cline { 2 - 5 } Language & basic & no mention & thank you & $\begin{array}{r}\text { moral } \\
\text { judgment }\end{array}$ \\
\cline { 2 - 5 } & & & & \\
Afrikaans & 30.0 & 20.0 & 45.0 & 5.0 \\
Dutch & 8.7 & 13.0 & 78.3 & 0.0 \\
(Belgium) & & & & \\
Catalan & 20.0 & 5.0 & 70.0 & 5.0 \\
German & 27.3 & 36.4 & 36.4 & 0.0 \\
English (UK) & 11.8 & 5.9 & 82.0 & 0.0 \\
English (US) & 0.0 & 50.0 & 50.0 & 0.0 \\
French & 0.0 & 21.1 & 78.9 & 0.0 \\
Greek & 25.0 & 35.0 & 40.0 & 0.0 \\
Irish & 21.7 & 17.4 & 56.5 & 4.3 \\
Italian & 38.1 & 23.8 & 38.1 & 0.0 \\
Polish & 20.0 & 20.0 & 60.0 & 0.0 \\
Spanish & 25.0 & 20.0 & 45.0 & 10.0 \\
Total & & & & \\
& 18.2 & 22.7 & 57.0 & 2.1 \\
\hline \hline
\end{tabular}

In summary, only $18.2 \%$ of the descriptions were neutral. More than half of the participants $(57.0 \%)$ interpreted the giving of the pears to the boys as a thank-you gesture, whereas only $2.1 \%$ provided a moral judgment of this event (an example from Catalan: 'It seems that the boy who found the hat on the ground and didn't show much solidarity asks him for 3 pears in return for the favour). When it comes to interpreting the event as a thank-you gesture, in most of the texts the actual verb thank was used or a word or phrase similar to thanks, such as odwdzięczać się 'to reciprocate', $w$ podzięce 'as a thank you' in Polish, or als dank 'by way of thanks' in Dutch. However, in the descriptions, phrases corresponding to the English phrase in return or in exchange - such as a canvi (Catalan), w zamian, w rewanżu (Polish) or in ruil (Dutch) - were also common. Such descriptions were also treated as interpreting the event as a thank-you gesture.

Given the above results and examples, it can be concluded that when describing the type of behaviour such as the one in the analysed case, people tend to interpret it - if only to a limited extent (e.g., as a thank-you gesture or doing something in return). ${ }^{\text {ii }}$ Rarer are descriptions with extremely subjective interpretations or (moral) judgments. This could imply that in AD such objective interpretations may be used since they are in line with how sighted viewers perceive and describe events. However, far-fetched interpretations which involve some kind of (moral) judgment should be avoided.

\subsection{Taking the pears}

This analysis refers to a scene where the boy on the bike takes one of the baskets that the pearpicker has filled with pears and rides off. The categories in this analysis are similar to those included in the analysis in Section 4.1. What we were most interested in here was whether event was described in neutral terms (e.g., the boy takes the basket) or whether it was interpreted as stealing (e.g., the boy steals the basket of pears). What was also interesting was whether there was any moral judgment of the act on the part of the participants (e.g., he takes the basket, which is wrong). The results of the analysis are presented in Table 2.

Table 2. Taking pears - results (in percent)

\begin{tabular}{lccrr}
\hline \hline & \multicolumn{4}{c}{ Reference to event } \\
\cline { 2 - 5 } Language & no mention & basic & stealing & $\begin{array}{r}\text { moral } \\
\text { judgment }\end{array}$ \\
\hline Afrikaans & 0.0 & 76.5 & 23.5 & 0.0 \\
Catalan & 0.0 & 25.0 & 75.0 & 0.0 \\
German & 0.0 & 83.3 & 16.7 & 0.0 \\
English (UK) & 0.0 & 44.4 & 55.5 & 0.0
\end{tabular}


This is an Author's Accepted Manuscript of a chapter in Remael, Aline; Pilar, Orero; Mary, Carroll (eds.) Audiovisual Translation and Media Accessibility at the Crossroads. Media for All 3. Amsterdam / New York: Rodopi, 173-188, available here:

http://www.rodopi.nl/functions/search.asp?Bookld=ATS+36

\begin{tabular}{lrrrr} 
English (US) & 0.0 & 65.0 & 30.0 & 5.0 \\
French & 0.0 & 36.8 & 63.2 & 0.0 \\
Greek & 15.0 & 60.0 & 25.0 & 0.0 \\
Irish & 0.0 & 55.0 & 40.0 & 5.0 \\
Italian & 0.0 & 44.0 & 52.0 & 4.0 \\
Polish & 0.0 & 90.0 & 10.0 & 0.0 \\
Spanish & 5.0 & 30.0 & 60.0 & 5.0 \\
& & & & \\
Total & 1.9 & 54.0 & 42.2 & 1.9 \\
\hline
\end{tabular}

The data show that the majority of the subjects $(54.0 \%)$ provided a neutral description of the deed. As few as $1.9 \%$ of the participants expressed any moral judgment of this event whereas $42.2 \%$ interpreted it as stealing. However, it should be noted that some descriptions which were counted as unbiased, later on included phrases that implied the act of stealing (e.g., the man who he has stolen from or the boy and the stolen pears fall on the ground (English (UK) examples). iii What is more, in most of the neutral descriptions of the boy taking the basket, it was often added that he makes sure that his deed will go unnoticed, which in itself could be considered interpretation. Also, in some interpretations the boy first considers taking only one pear out of the basket, but then decides to take the entire basket. In some cases, the participants even provided the rationale for stealing the basket, as in the following example from Italian: ... a little boy with a bicycle - probably a poor boy, or maybe he's fine and simply hungry - steals one basket.

Interestingly, although the results in the last category (moral judgment) are very similar to the results in 4.1, there is no consistency in neutral versus interpretive descriptions in the two aspects analysed so far. The difference could perhaps be attributed to the fact that interpreting the giving of the pears as a thank-you gesture does not imply any judgment about this event, whereas describing the taking of the basket as stealing is in fact a (moral) judgment in itself, which some of the participants may have wanted to avoid in their descriptions. Another reason could be the young age of the protagonist. It is possible that people are not at ease evaluating the deeds of children by the same standards as those of adults.

Given the above results, it seems that when audio describing this scene a neutral description of the boy taking the basket would probably be more appropriate than describing it as stealing. However, surmising the motivation behind the boy's action should be avoided at all costs.

\subsection{The pearpicker's discovery}

This analysis refers to the scene following the one analysed in Section 4.2. In this third scene, the pearpicker discovers that the basket is gone. Again, we wanted to see whether the descriptions provided were basic, neutral accounts of the event (e.g. he notices that the basket is gone) or whether they provided information about either emotions or a reaction of the pearpicker (e.g., the picker is surprised/angry/sad etc. to see that the basket is gone), or both the emotions and the reaction (e.g., the picker is surprised to see the basket gone and looks suspiciously at the boys). We also wanted to investigate whether the descriptions included any interpretation of the pearpicker's reaction on the part of the participants (e.g., the picker suspects that the boys who are eating the pears stole the basket). The results of the analysis are presented in Table 3.

Table 3. The pearpicker's discovery - results (in percent)

\begin{tabular}{|c|c|c|c|c|c|}
\hline \multirow[b]{2}{*}{ Language } & \multicolumn{5}{|c|}{ Reference to event } \\
\hline & no mention & basic & $\begin{array}{r}\text { describe } \\
\text { emotions or } \\
\text { reaction }\end{array}$ & interpret & $\begin{array}{r}\text { describe } \\
\text { emotions } \\
\text { and } \\
\text { reaction }\end{array}$ \\
\hline Afrikaans & 0.0 & 36.8 & 47.4 & 10.5 & 5.3 \\
\hline Catalan & 5.0 & 20.0 & 40.0 & 5.0 & 30.0 \\
\hline German & 10.0 & 40.0 & 30.0 & 10.0 & 10.0 \\
\hline English (UK) & 10.0 & 30.0 & 30.0 & 25.0 & 5.0 \\
\hline English (US) & 0.0 & 30.0 & 30.0 & 25.0 & 15.0 \\
\hline French & 5.3 & 36.8 & 42.1 & 5.3 & 10.5 \\
\hline Greek & 20.0 & 25.0 & 10.0 & 35.0 & 10.0 \\
\hline Irish & 15.0 & 50.0 & 25.0 & 10.0 & 0.0 \\
\hline
\end{tabular}


This is an Author's Accepted Manuscript of a chapter in Remael, Aline; Pilar, Orero; Mary, Carroll (eds.) Audiovisual Translation and Media Accessibility at the Crossroads. Media for All 3. Amsterdam / New York: Rodopi, 173-188, available here: http://www.rodopi.nl/functions/search.asp?Bookld=ATS+36

\begin{tabular}{lrrrrr} 
Italian & 22.2 .0 & 50.0 & 11.1 & 5.6 & 11.1 \\
Polish & 0.0 & 35.0 & 45.0 & 15.0 & 5.0 \\
Spanish & 10.0 & 35.0 & 40.0 & 15.0 & 0.0 \\
& & & & & \\
Total & 8.8 & 35.0 & 32.0 & 15.0 & 9.2 \\
\hline
\end{tabular}

When looked at individually, the results above suggest that the majority of the subjects provided a neutral description of the event. However, given the purpose of the analysis, it seems reasonable to combine the results for the categories 'describe emotions or reaction' and 'describe emotion and reaction' since they both pertain to some degree of interpretation of how the pearpicker responded to the basket having disappeared. If this is the case, we can therefore conclude that most of the descriptions (i.e., $41.2 \%$ ) were biased and did interpret the pearpicker' behaviour in one way or another.

With regard to the actual descriptions of the emotions/reactions, most of the above-mentioned $41.2 \%$ of participants reported that the pearpicker was 'surprised' to see that the basket had gone. This result appears to be in line with Orero's and Vercauteren's claim that some emotions are universal and can be correctly identified (see Section 2.2). For this reason, describing the actual emotion rather than the facial expression that underlies it is recommended for writing AD. Coming back to the case in point, it could be assumed that if this particular scene was to be audio described, the describer - irrespective of the time constraints - could actually name the pearpicker's reaction rather than describe the facial expression that points to the reaction.

When it comes to cases of more subjective interpretations, some subjects made assumptions as to why the pearpicker did not react to the taking of the basket, an example being: However he does not say anything, so maybe the young boy who took the basket was actually supposed to collect it from the man? (English (UK) data). Moreover, when compared with the results for the more subjective interpretations obtained in the two previous analyses (i.e., $2.1 \%$ and $1.9 \%$ respectively), the result obtained in this third analysis is surprisingly high $(15.0 \%)$. This could be due to the fact that no actual moral judgment, but merely subjective assessment of the situation is given. Despite the reason for the higher result, it seems that this type of interpretation is excessive and would not be appropriate in $\mathrm{AD}$ since it would involve some degree of character mind-reading on the part of the audio describer.

\section{Conclusions}

Although we are aware that the issue of interpretation in $\mathrm{AD}$ will probably continue to divide $\mathrm{AD}$ practitioners and researchers in the years to come and may never be fully resolved, we would like to propose that instead of the binary opposition of objective versus subjective we should rather be working with a scale with objective and subjective at the two extremes and varying degrees of objectivity and subjectivity in between. We also believe that studies investigating the narrative behaviour of sighted viewers - as the one presented in this contribution can shed more light on what types of visual stimuli tend to be interpreted universally and where to place such descriptions on the objectivity-subjectivity scale. In turn, this could help us avoid audio descriptions that are patronising and that spoon-feed the sense to the visually impaired.

The analyses have shown that sighted viewers tend to interpret visual events, but interestingly they avoid extremely subjective interpretations that include a (moral) judgment or subjective assessment of the situation. In the three aspects analysed, such descriptions constituted as little as $2.1 \%, 1.9 \%$ and $15.0 \%$ respectively of all the descriptions. When it comes to the prevailing descriptions in the aspects analysed, the giving of the pears was interpreted as a thank-you gesture by the majority of the subjects (57\%), whereas the taking of the basket by the boy was described in neutral terms by most of the subjects (54\%) rather than as stealing $(42.2 \%)$, which in itself is a form of a moral judgment. With regard to the last of the aspects analysed, most of the descriptions interpreted the reaction of the pearpicker to the basket being gone as surprise (41.2\%). This last example is particularly interesting from the point of view of the debate on whether to audio describe facial expressions or whether to name the emotions that are manifested through them. This result suggests that the latter should be the case, as most of us are capable of deciphering such emotions correctly and consistently.

To conclude, when it comes to interpretation in $\mathrm{AD}$, we believe that not only reception research on the specific requirements and preferences of the blind and partially-sighted viewers but also studies on human perception and narrative behaviour in general can help us produce audio description of better quality. 
This is an Author's Accepted Manuscript of a chapter in Remael, Aline; Pilar, Orero; Mary, Carroll (eds.) Audiovisual Translation and Media Accessibility at the Crossroads. Media for All 3. Amsterdam / New York: Rodopi, 173-188, available here:

\section{http://www.rodopi.nl/functions/search.asp?Bookld=ATS+36}

i Please note that not all of the languages are covered in all of the discussed aspects, as some countries provided data for a number of aspects

ii It may be the case that such limited interpretations could be considered as the interpretation of culture-bound but recognizable situations of interaction between people, e.g. involving rules of politeness. This, in turn, could turn mean that descriptions by non-Europeans might be different in this respect. This issue, however, requires further investigation.

${ }^{\text {iii }}$ Such descriptions were nonetheless counted as neutral, as in this aspect what was looked at was the very act of taking the pears. It should, however, be noted that the very fact that a given description of the event is neutral does not necessarily mean that it was not interpreted as e.g. stealing by the describer.

\section{References}

Braun, Sabine. 2007. 'Audio Description from a Discourse Perspective: A Socially Relevant Framework for Research and Training' in Linguistica Antverpiensia NS 6: 357-372.

Chafe, Wallace (ed.). 1980. The Pear Stories: Cognitive, Cultural and Linguistic Aspects of Narrative Production. Norwood, New Jersey: Ablex Publishing.

Chmiel, Agnieszka and Iwona Mazur (forthcoming). 'Audiodeskrypcja jako intersemiotyczny przekład audiowizualny - percepcja produktu i ocena jakości’. To appear in an edited collection to be published by Leksem publishing house.

- (forthcoming). 'Overcoming Barriers - the Pioneering Years of Audio Description in Poland". To appear in Serban, Adriana, Anna Matamala and Jean-Marie Lavaur (eds) Audiovisual Translation in Close-up: Practical and Theoretical Approaches.

Dosch, Elmar and Bernd Benecke. 2004. Wenn aus Bildern Worte Werden. Durch Audio-Description zum Hörfilm. Bayerischer Rundfunk: München.

Du Bois J.W. 1980. 'Introduction - The Search for a Cultural Niche: Showing the Pear Film in a Mayan Community' in Chafe, Wallace (ed.) The Pear Stories: Cognitive, Cultural and Linguistic Aspects of Narrative Production. Norwood, NJ: Ablex Publishing. 1-7.

Holland, Andrew. 2009. 'Audio Description in the Theatre and the Visual Arts: Images into Words' in Anderman, Gunilla and Jorge DíazCintas (eds) Audiovisual Translation. Language Transfer on Screen. Basigtoke: Palgrave Macmillan: 170- 185.

Hyks, Veronika. 2006. 'Translation versus Origination, Creativity within Limits'. On line at: http://www.languagesmedia.com/lang media 2006/protected/Veronika Hyks.pdf (consulted 15.04.2010).

ITC on Standards for Audio Online http://www.ofcom.org.uk/static/archive/itc/uploads/ITC Guidance On Standards for Audio Description.doc (consulted 15.04.2010)

Mazur, Iwona and Agnieszka Chmiel (manuscript in preparation). 'Towards a Common European Quality Audio Description: Final Report on the Pear Tree Project'.

Orero, Pilar. 2005. 'Audio Description: Professional Recognition, Practice and Standards in Spain' in Translation Watch Quarterly Vol. 1: 718 .

Orero, Pilar and Gert Vercauteren (manuscript in preparation). 'The Importance of Adequate Descriptions of Facial Behaviour: Cognition beyond Description'

Pujol, Joaquim and Pilar Orero. 2007. 'Audio Description Precursors: Ekphrasis and Narrators' in Translation Watch Quarterly 3(2): 49-60.

Rai, Sonali. $2009 . \quad$ Bollywood for All. http://www.rnib.org.uk/aboutus/Research/reports/accessibility/Documents/2009 09 Bollywood AD report.pdf (consulted 12.04.2010)

Remael, Aline. 2005. 'Audio Description for Recorded TV, Cinema and DVD. An Experimental Stylesheet for Teaching Purposes'. On line at: www.hivt.be (consulted 12.04.2010).

Snyder, Joel. 2005. 'Audio Description. The Visual Made Verbal across Arts Disciplines - across the Globe' in Translating Today 4: 15-17.

- 2007. 'Audio Description: The Visual Made Verbal' in The International Journal of the Arts in Society. On line at: http://www.audiodescribe.com/about/articles/ad international journal 07.pdf (consulted 12.04.2010).

Tannen, Deborah. 1980. ‘A Comparative Analysis of Oral Narrative Strategies: Athenian Greek and American English' in Chafe, Wallace (ed.) The Pear Stories: Cognitive, Cultural and Linguistic Aspects of Narrative Production. Norwood, NJ: Ablex Publishing. 5187 .

'The play's the thing: Audio description in the theatre: Margaret and Cody Pfanstiehl' [an interview]. 1985. British Journal of Visual Impairment 3(3): 91-92.

Udo, John Patrick and Deborah I. Fels. 2009. 'Suit the Action to the Word, the Word to the Action: An Unconventional Approach to Describing Shakespeare's Hamlet' in Journal of Visual Impairment \& Blindness 103(3): 178-183.

Vercauteren, Gert. 2006. 'Practical Guidelines for Audio Description'. Paper presented at the Audiovisual Translation Scenarios Conference (University of Copenhagen, 1-5 May 2006). 